\title{
The Bank Sector Performance and Macroeconomics Environment: Empirical Evidence in Togo
}

\author{
Adama Combey ${ }^{1} \&$ Apélété Togbenou ${ }^{2}$ \\ ${ }^{1}$ Central Bank of West African States, Lome, Togo \\ ${ }^{2}$ Ministry of Development Planning of Togo, Lome, Togo \\ Correspondence: Adama Combey, Central Bank of West African States, Lome, Togo. Tel: \\ 228-2223-5205/228-9011-9692. E-mail: adama.combey@gmail.com/apelete.togbenou@gmail.com
}

Received: December 12, 2016

Accepted: December 28, 2016

Online Published: January 10, 2017

doi:10.5539/ijef.v9n2p180

URL: http://dx.doi.org/10.5539/ijef.v9n2p180

\begin{abstract}
This article investigates short-run and long-run relationship between three main macroeconomic indicators (gross domestic product growth, real effective exchange rate, and inflation) and banking sector profitability (measured by return on assets and return on equity) in Togo, from 2006 to 2015, by using Pool Mean Group estimator. Results show that, in the short-run, banks' return on assets and return on equity are not related to macroeconomic variables. But banks' return on assets is determined positively by bank capital to assets ratio and bank size while banks' return on equity is affected negatively by bank capital to assets ratio. However, in the long-run, real gross domestic product growth and real effective exchange rate affect negatively and statistically significant banks' return on assets, while inflation rate has no effect. Concerning bank's return on equity, in the long-run, results suggest that real gross domestic product growth, real effective exchange rate, and inflation affect negatively bank's return on equity. These results imply that to stabilize bank profitability and make Togolese banking sector more resilient, policymakers and banking sector managers must, among others, try to improve real gross domestic product growth, real effective exchange rate, and inflation volatility anticipation.
\end{abstract}

Keywords: bank, performance, macroeconomics environment, pool mean group

\section{Introduction}

The bank sector performance and macroeconomic environment nexus analysis has recently reappeared in the economic and financial literature, because one lesson learned from 2007-2009 financial crises is that banking sector performance and it resilience depend on macroeconomic environment.

Diamond-Dybvig et al. (1983) show that if bank solvency and liquidity ratio decline, macroeconomics shocks, such as great variability of economic growth, exchange rate, or inflation, lead to banking crises and bankruptcy, and therefore required policymakers interventions in banking system. In addition, unfavorable or favorable commercial banks balance sheets may induce a contraction or expansion of distributed credit, which in turn amplify the impact of these shocks on output and inflation (Christensen et al., 2011).

From 1991 to 1993, Togo has experienced macroeconomics shocks with a decrease in economic growth about 15.1 percent in 1993. As result, banks' performance has deteriorated and this country has experienced two years banking crisis: 1993 and 1994.

As theoretical models pointed out that banking crises are very costly for the economy and require adjustments up to bailout of some banks, as was the case in the Unit States of America during the recent financial crisis, policymakers in developing countries pay more attention to banks' performance indicators evolution.

Recently, Togolese bank's non-performing loans have deteriorated, rising from 11.4 percent in 2011 to 16.7 percent in 2015. Thus, bank's return on assets declined from 2.4 percent in 2008 to 0.89 percent in 2015 . Furthermore, Z-score, defined as the number of standard deviations that a bank's return on asset has to fall for the bank to become insolvent (Köhler, 2015) decreased from 6.1 in 2006 to 3.6 in 2015. This situation pointed out the bank's solvency risk because returns are volatile and induced decline in banking sector buffers.

However, since 2010, Togolese economy has returned to vigorous economic growth, under favorable macroeconomic conditions: economic growth rate, inflation rate and real effective exchange (annual percentage) averaged to $5.12 \%, 2.0 \%$, and $-1.2 \%$, respectively, from 2010 to 2014 . 
These stylized facts raise questions about banking sector performance and macroeconomic environment nexus in Togo: Does macroeconomic factors affect banking sector performance in term of profitability? This paper is the first focusing on this analysis in the Togolese context.

The articles which have treated the subject in the literature indicate that banking sector performance would positively relate, among others, to GDP growth, terms of trade, and would negatively affect by inflation and exchange rate. To our knowledge, existing studies on the area are limited on banking sector performance determinants (Tanimoune \& Cloutier, 2009), its solvency, failure and resilience (Powo Fosso, 2000), or banks' stress-test (Gammadigbé, 2012) and cover West African Economic and Monetary Union region.

This article extends the literature on banking sector performance and macroeconomic environment nexus by exploring the short-run and the long-run factors in Togo, and by using recent econometric literature. The paper aim to provide a better understanding on banking sector performance and macroeconomic environment nexus in this country.

The rest of this article is organized as follows. Next section offers an overview of theoretical and empirical literature. Section three exposes the methodological approach and section four presents results, discussion, and analysis. Conclusion and policy implications are provided in the last section.

\section{Overview of the Literature}

According to economic and financial literature, two main indicators permit measuring the bank performance in term of profitability (ROA and ROE). Volatility of these two indicators, compared to the bank buffers (capitalization and return), allow assessing the bank's solvency risk. This risk is measured by the so-called $\mathrm{Z}$-score. An increase in Z-score value indicates a decrease in bankruptcy probability.

Theoretical models show that there is an interaction between banking performance, solvency risk and macroeconomic indicators, such as gross domestic product, inflation, and real effective exchange rate. However, whether theory or empirical studies, results are ambiguous for certain factors and often seem depending on particular data sets, sample choices, and specifications.

\subsection{Theory}

Theoretical models indicate that internal factors like liquidity, bank size, capitalization, operating efficiency, growth opportunities, affect banking performance and it solvency risk as well as macroeconomic indicators, such as gross domestic product, inflation, and real effective exchange rate. This section presents theoretical overview about the relationship between banking performance and macroeconomic variables.

\subsubsection{Gross Domestic Product}

In theory, real GDP growth affects positively banking performance through three mains channels: net interest income, loan losses improving, and operating costs (Jiménez et al., 2009; Bolt et al., 2012; Calza et al., 2006). Firm's profitability increases during economic expansion, and declines in recession's period. Thus, a higher GDP growth causes firms loans and deposits to increase and make bank's net interest income and loans losses to improve. Also, a higher GDP growth implies a higher disposable income, and lower unemployment and reduce defaults on consumer loans number. Net interest income and loan losses are therefore pro-cyclical with GDP growth.

However, the relation between bank's operating costs and GDP growth is ambiguous. Bolt et al. (2012) show that unfavorable economic conditions, such as lower GDP growth rates may decrease deposits and loans and its managing costs as well. These conditions may also it possible raise the costs of collecting payments on loans.

\subsubsection{Inflation}

The relation between inflation and banking performance has been introduced in the theory by Revell (1979). He shows that inflation affects bank's profitability through its effect on overhead costs, in particular salaries and operating costs. If inflation rate increases, it may raise salaries and operating costs, and therefore decrease bank's profitability. But if the inflation rate is fully anticipated by the bank's management, the bank can adjust interest rates appropriately to increase revenues faster than costs, which should have a positive impact on profitability (Trujillo-Ponce, 2013).

\subsubsection{Real Effective Exchange Rate}

As Adler and Dumas (1980) pointed out, bank's activities are exposed to exchange rates because asset value volatility on the exchange rates. Chamberlain et al. (1997) show that exchange rates affect most directly those banks with foreign currency transactions and foreign operations, and even without such activities, exchange rates 
can affect banks indirectly through their influence on foreign competition, the demand for loans, and other aspects of banking conditions.

A lower exchange rate promotes competitiveness of firms because goods manufactured prices at home decline and foreign demand raise (Luehrman, 1991). As a result, loans and deposits increase as well as banks' profits. But a lower exchange rate may also reduce domestic consumer purchasing power, as imported goods become more expensive. This situation may increase loans losses and may have negative effects on bank's profitability.

\subsection{Empirical Evidence}

Most empirical studies in developing countries, focusing on the bank's profitability and macroeconomics environment. Recently, Sufian and Habibullah (2010) show that economic growth affects positively banks' profitability in Indonesia from 1990 to 2005. Acaravci and Çalim (2013) confirm this find on the Turkish Banking sector. However, Simiyu and Ngile (2015) find that real GDP growth rate has positive but insignificant effect on the ROA in the Nairobi from 2001 to 2012.

On the other hand, Tan and Floros (2012) find a negative relationship between GDP growth and bank's profitability in China over the period 2003-2009. Francis (2013) reveals the same result in 42 Sub-Saharan countries from 1999 to 2006, while Masood, and Ashraf (2012) show that real GDP has a negative effect on banks' ROA, and a positive effect on ROE

Concerning the inflation, Demirgüc-Kunt and Huizinga (1999) show that inflation rate has positive impact on banks' performance because banks manage their costs well under high inflation and Bashir (2003) finds the same results in the Middle Eastern Islamic banks' sector, while Asutay and Izhar (2007) find a negative and significant relationship between banks' profitability and inflation in Indonesia as well as Khrawish (2011) suggest that there is a significant and negative relationship between commercial banks ROA and inflation rate in Jordanian from 2000 to 2010.

Furthermore, Scott and Ovuefeyen (2014) suggest that inflation adversely affected commercial banks' profitability in the heat of the global financial crisis (2007-2010) in Nigeria, marked by the downward trends in return on asset of most of the banks within the period.

However, Saad and El-Moussawi (2012) reveal that the inflation in Lebanon does not impact commercial banks' profitability.

About exchange rate, in Nigeria, Isaac (2015) indicates that unit increases in exchange rate is driven by an increase in profit after tax and equally shows that there is a significant relationship between exchange rate management and performance of financial institutions, most especially banks. Moreover, Aburime (2009) suggests that the exchange rate regimes are significant macroeconomic determinants of banks' profitability in Nigeria from 1980 to 2006.

But Addae et al. (2014) demonstrate that all the banks studied engage in forex trading and made profits from such activities in Ghana and suggest that apart from Ghana Commercial Bank and Standard Chartered Bank who were exposed to foreign exchange risk, all the banks, on the other hand, have risk management structures in place to mitigate any risks that arise as a result of their operations.

Osuagwu (2014) indicate that exchange rate is significant as a determinant of bank profitability through return on equity and non-interest margin, but not significant to return on asset as a measure of profitability in Nigeria.

\section{Methodology and Data}

\subsection{Model Specification}

To investigate the relationship between bank's profitability and macroeconomics environment in Togolese context, a standard representation of bank's profit function are mobilized as follows:

$$
Y_{i, t}=\theta_{0 \mathrm{t}}+\alpha_{i} Z_{i, t}+\beta_{i} X_{i, t}+\mu_{i}+\varepsilon_{i, t}
$$

Yi,t represents profitability indicators of bank $\mathrm{i}$ in time t. This paper focuses on ROA and ROE. $Z_{\mathrm{i}, \mathrm{t}}$ represents macroeconomics factors such as real gross domestic product growth (GDP), real effective exchange rate (RER), and inflation rate (INFL). $\mathrm{X}$ is a set of control variables, banks' internal factors informed by both theory and empirical in developing countries evidence like bank size (BS) and Bank Capital to Assets Ratio (CAR). $\mu$ i is a heterogeneous factor specific for each bank and $\varepsilon_{\mathrm{i}, \mathrm{t}}$ is independent and identically distributed (i.i.d) with mean zero and finite variance $\sigma_{2}$.

\subsection{Data Description and Pre Diagnostic Tests}

The data set consist of annual observations, from 2006 to 2015, and cover nine commercial banks of Togo. Gross 
domestic product growth and real effective exchange rate have been gained from the data set of World Development Indicators, inflation rate, from the Central Bank of West African States database, while return on assets, return on equity, bank capital to assets ratio, and bank size were obtained from the Banking Commission of the WAEMU annual reports (See Appendix for construction details, definition and each variable sources).

As Combey (2016) pointed out, it becomes a common wisdom in panel data analysis that econometric methodology involves a battery of pre and post diagnostic tests, checking for unit root and co-integration.

The results of panel unit root tests of Levin, Lin, and Chu (2002); Im, Pesaran, and Shin (2003); and Maddala and $\mathrm{Wu}$ (1999), and Choi (2001), suggest that inflation rate and real exchange rate are stationary in level $\mathrm{I}(0)$, while gross domestic product growth, return on assets, return on equity, bank capital to assets ratio, and bank size are stationary in first difference I(1) (Table 1).

In addition, Westerlund (2007) tests conclude that the null hypotheses of no co-integration between dependent variables (return on assets, return on equity) and certain independent variables (gross domestic product growth, bank capital to assets ratio, and bank size) are rejected (Table 2).

Table 1. Summary results of panel unit root tests

\begin{tabular}{lcccc}
\hline Variables & Levin, Lin \& Chu & Im, Pesaran and Shin & Maddala and Wu & Order of integration \\
\hline GDP, first difference & $-4.6^{* * *}$ & $-3.9^{* * *}$ & $-4.5^{* * *}$ & $\mathrm{I}(1)$ \\
RER, level & $-4.8^{* * *}$ & $-3.6^{* * *}$ & $-2.3^{* * *}$ & $\mathrm{I}(0)$ \\
INFL, level & $-4.0^{* * *}$ & $-3.1^{* * *}$ & $-2.1^{* * *}$ & $\mathrm{I}(0)$ \\
ROA, first difference & $-21.8^{* * *}$ & $-2.4^{* * *}$ & $-6.0^{* * *}$ & $\mathrm{I}(1)$ \\
ROE, first difference & $-17.1^{* * *}$ & $-3.7^{* * *}$ & $-6.7^{* * *}$ & $\mathrm{I}(1)$ \\
CAR, first difference & $-37.9^{* * *}$ & $-1.6^{* *}$ & $-4.8^{* * *}$ & $\mathrm{I}(1)$ \\
BS, first difference & $-27.8^{* * *}$ & $-2.3^{* * *}$ & $-5.5^{* * *}$ & $\mathrm{I}(1)$ \\
\hline
\end{tabular}

Source: Authors, $* * *, * *$, and $*$ indicate that the statistic is statistically significant at the $1 \%, 5 \%$, and $10 \%$ levels, respectively. The null hypothesis of stationarity tests are $=$ Non stationarity.

Table 2. Westerlund error correction based panel co-integration tests

\begin{tabular}{lcccccccc}
\hline \multirow{2}{*}{ Variables } & \multicolumn{3}{c}{ Return On Assets, ROA } & \multicolumn{4}{c}{ Return On Equity, ROE } \\
\cline { 2 - 9 } & $\mathrm{Gt}$ & $\mathrm{Ga}$ & $\mathrm{Pt}$ & $\mathrm{Pa}$ & $\mathrm{Gt}$ & $\mathrm{Ga}$ & $\mathrm{Pt}$ & $\mathrm{Pa}$ \\
\hline GDP & $-18.6^{* * *}$ & 3.6 & $-3.2^{* * *}$ & -0.5 & -1.1 & -1.1 & $-2.1^{*}$ & -1.9 \\
RER & 2.2 & 3.1 & 0.4 & 0.9 & 0.6 & 1.8 & 1.8 & 1.8 \\
INFL & 2.0 & 3.6 & -0.1 & 0.9 & 1.5 & 1.8 & 0.2 & 1.0 \\
CAR & $-3.5^{* * *}$ & 0.7 & $-1.3 * * *$ & 0.3 & -1.2 & 1.7 & -2.8 & 0.3 \\
BS & $-5.3^{* * *}$ & 4.0 & 2.5 & 2.3 & $-12.1 * * *$ & $-1.7 *$ & -2 & -0.3 \\
\hline
\end{tabular}

Source: Authors, $* * *, * *$, and $*$ indicate that the statistic is statistically significant at the $1 \%, 5 \%$, and $10 \%$ levels, respectively. The null hypothesis of Westerlund test is = Non co-integration.

\subsection{Estimation Techniques}

This feature of data implies an Error Correction Model Specification in which the short-run dynamics of the variables in the system are influenced by the deviation from equilibrium. Thus, the equation (1) is become as follows.

$$
\Delta Y_{i, t}=a_{0, i}\left(Y_{i, t-1}-\theta_{0 \mathrm{t}}-\mu_{i}-\alpha_{i} Z_{i, t}-\beta_{i} X_{i, t}\right)+\mathrm{Y}_{i} \Delta Z_{i, t}+\delta_{i} \Delta X_{i, t}+\varepsilon_{i, t}
$$

The parameter $\mathrm{a}_{0, \mathrm{i}}$ is the error-correcting speed of adjustment term. If $\mathrm{a}_{0, \mathrm{i}}=0$, then there would be no evidence for the long-run relationship. This parameter is expected to be significantly negative under the prior assumption that the variables show a return to a long-run equilibrium.

The recent literature on dynamic heterogeneous panel estimation, in which both $\mathrm{N}$ and $\mathrm{T}$ are large, with a co-integration mixed of $\mathrm{I}(0)$ and $\mathrm{I}(1)$ variables, suggests several approaches to estimate equation (2) (See Blackburne and Frank (2007) for more details).

On one extreme, a Dynamic Fixed-Effects (DFE) estimation approach could be used in which the time-series data for each bank are pooled and only the intercepts are allowed to differ across banks. If the slope coefficients are in fact not identical, however, the DFE approach produces inconsistent and potentially misleading results. On the other extreme, the model could be fitted separately for each bank, and a simple arithmetic average of the 
coefficients could be calculated. This is the Mean Group (MG), estimator proposed by Pesaran and Smith (1995). With this estimator, the intercepts, slope coefficients, and error variances are all allowed to differ across bank.

More recently, Pesaran, Shin, and Smith $(1997,1999)$ have proposed a Pooled Mean Group (PMG) estimator that combines both pooling and averaging. This intermediate estimator allows the intercept, short-run coefficients, and error variances to differ across the banks (as would the MG estimator) but constrains the long-run coefficients to be equal across banks (as would the DFE estimator). Hausman specification test is performed to obtain the estimator that is efficient and consistent according to the data feature.

\section{Results, Analysis and Discussion}

Results are reported in Table 3, 4 and 5. Its indicate that the Pooled Mean Group estimator, the efficient estimator under the null hypothesis, is preferred to Mean Group estimator, both for ROA and ROE models. It's also confirm that the Pooled Mean Group estimator is more efficient and consistent than the Dynamic Fixed-Effects estimator, according to Hausman test, checking for endogeneity between the error term and the lagged dependent variables (Table 5).

Moreover, the error correction term, the adjustment coefficient, has a negative and statistically significant value and average to -1.0 for ROA models and -0.94 for ROE models (Table 4). These imply that, models are dynamically stables, and banks' return on assets and return on equity in Togo adjust fast to equilibrium levels in the current period, from a disequilibrium experienced in the previous period after a shock to any of its determinants.

Furthermore, results suggest that, in the short-run, banks' return on assets and return on equity are not related to macroeconomics variables (Table 3). But banks' ROA is determined positively by bank capital to assets ratio and bank size, while banks' ROE is affected negatively by bank capital to assets ratio. Their coefficients are statistically significant and do not change largely when we introduce one by one macroeconomics variables, confirming the relationship robustness. The bank capital to assets ratio and bank size short-run coefficients for banks' ROA are average to 0.42 and 8.3, respectively, and the bank capital to assets ratio short-run coefficient for banks' ROE is average to -3.8 .

However, in the long-run, real gross domestic product growth and real effective exchange rate affect negatively and statistically significant banks' return on assets, while inflation rate has no effect on banks' return on assets (Table 4). The real gross domestic product growth and real effective exchange rate long-run coefficients are -1.5 and -0.06 , respectively. These finds imply that a one percentage point increase in real gross domestic product growth may declines in overall 1.5 percentage of banks' return on assets.

This find is contradictory with theoretical predictions of the relationship between bank's return on assets and real GDP growth, but confirming Francis (2013) revelation in Sub-Saharan context. This result pointed out the debate about banking sector in Sub-Saharan, most especially Togolese baking sector capacities to manage loans losses and loans originate in GDP expansion period.

Furthermore, when the real effective exchange rate decreases of one percentage point, banks' return on assets may increase about 0.06 percent. This find is consistent with the theoretical predictions of relationship between bank's return on assets and real effective exchange rate, when the positive firms' competitiveness effect dominates the negative domestic consumer purchasing power effect.

Concerning bank's return on equity, long-run results show that real GDP growth, real effective exchange rate, and inflation affect are negatively related to bank's return on equity. The real GDP growth, real effective exchange rate, and inflation long-run coefficients are $-6.47,-2.71$, and -2.01 , respectively. These finds imply that a one percentage point increase in real GDP growth, real effective exchange rate, and inflation may declines in overall $6.47 \%, 2.71 \%$, and $2.01 \%$ of banks' return on equity. Results confirm theoretical predictions of relationship between bank's return on equity and real effective exchange rate and inflation, while it infirm GDP relationship. The inflation impact on banks' return on assets passes through the bank capital to assets ratio. Indeed, this ratio loses it coefficient significance when we introduce inflation rate into the equation. This could be explained by the fact that a bad anticipation of inflation affects essentially banks' operating costs and the first amortization of this cost is banks' capital. 
Table 3. Results of short-run effects of macroeconomics effects on banks' profitability

\begin{tabular}{|c|c|c|c|c|c|c|c|c|}
\hline \multirow[b]{3}{*}{ Variables } & \multicolumn{8}{|c|}{ Banks' performance indicators } \\
\hline & \multicolumn{4}{|c|}{ Return On Assets, ROA } & \multicolumn{4}{|c|}{ Return On Equity, ROE } \\
\hline & Model1 & Model2 & Model3 & Model4 & Model1 & Model2 & Model3 & Model4 \\
\hline D.CAR & $\begin{array}{c}0.43 * * * \\
(0.15)\end{array}$ & $\begin{array}{c}0.16 \\
(0.18)\end{array}$ & $\begin{array}{c}0.36 \\
-0.24\end{array}$ & $\begin{array}{c}0.42 * * \\
(0.21)\end{array}$ & $\begin{array}{c}-3.44 * * \\
(1.62)\end{array}$ & $\begin{array}{c}-4.53 * * \\
(2.07)\end{array}$ & $\begin{array}{l}-1.69 \\
(3.52)\end{array}$ & $\begin{array}{c}-3.57 * * \\
(1.58)\end{array}$ \\
\hline D.BS & $\begin{array}{c}8.30 * * * * \\
(2.98)\end{array}$ & $\begin{array}{c}7.93 \\
(5.39)\end{array}$ & $\begin{array}{l}7.53 * * \\
(3.54)\end{array}$ & $\begin{array}{c}8.33 * * \\
(3.70)\end{array}$ & $\begin{array}{c}-2.99 \\
(34.46)\end{array}$ & $\begin{array}{l}-16.80 \\
(37.63)\end{array}$ & $\begin{array}{c}22.14 \\
(34.42)\end{array}$ & $\begin{array}{c}7.25 \\
(42.17)\end{array}$ \\
\hline D.GDP & & $\begin{array}{c}0.33 \\
(0.41)\end{array}$ & & & & $\begin{array}{c}4.01 \\
(3.13)\end{array}$ & & \\
\hline D.INFL & & & $\begin{array}{c}0.13 \\
-0.23\end{array}$ & & & & $\begin{array}{c}1.35 \\
(4.44)\end{array}$ & \\
\hline D.RER & & & & $\begin{array}{c}0.10 \\
(0.08)\end{array}$ & & & & $\begin{array}{c}0.14 \\
(2.06)\end{array}$ \\
\hline
\end{tabular}

Table 4. Results of long-run effects of macroeconomics effects on banks' profitability

\begin{tabular}{|c|c|c|c|c|c|c|c|c|}
\hline \multirow{3}{*}{ Variables } & \multicolumn{8}{|c|}{ Banks' performance indicators } \\
\hline & \multicolumn{4}{|c|}{ Return On Assets, ROA } & \multicolumn{4}{|c|}{ Return On Equity, ROE } \\
\hline & Model1 & Model2 & Model3 & Model4 & Model1 & Model2 & Model3 & Model4 \\
\hline $\mathrm{EC}$ & $\begin{array}{c}-1.19 * * * * \\
(0.20)\end{array}$ & $\begin{array}{c}-0.87 * * * \\
(0.20)\end{array}$ & $\begin{array}{c}-0.94 * * * \\
(0.19)\end{array}$ & $\begin{array}{c}-1.00 * * * \\
(0.19)\end{array}$ & $\begin{array}{c}-1.07 * * * \\
(0.12)\end{array}$ & $\begin{array}{c}-0.90 * * * \\
(0.15)\end{array}$ & $\begin{array}{c}-0.91 * * * \\
(0.13)\end{array}$ & $\begin{array}{c}-0.88 * * * * \\
(0.10)\end{array}$ \\
\hline CAR & $\begin{array}{c}-0.12^{* * * *} \\
(0.04)\end{array}$ & $\begin{array}{c}-0.163^{* * * *} \\
(0.01)\end{array}$ & $\begin{array}{c}-0.099 * * * \\
(0.03)\end{array}$ & $\begin{array}{c}-0.25 * * * \\
(0.03)\end{array}$ & $\begin{array}{c}-0.66^{* *} \\
(0.28)\end{array}$ & $\begin{array}{c}-0.63 * * * \\
(0.24)\end{array}$ & -0.1643 & $\begin{array}{c}-0.64 * * \\
(0.29)\end{array}$ \\
\hline BS & $\begin{array}{c}1.61 * * * \\
(0.19)\end{array}$ & $\begin{array}{c}3.13 * * * \\
(0.25)\end{array}$ & $\begin{array}{c}1.77 * * * \\
(0.27)\end{array}$ & $\begin{array}{c}2.04 * * * \\
(0.09)\end{array}$ & $\begin{array}{c}11.01 * * * \\
(3.26)\end{array}$ & $\begin{array}{c}32.96 * * * \\
(4.92)\end{array}$ & $\begin{array}{l}-1.33 \\
(3.31)\end{array}$ & $\begin{array}{l}8.54 * * \\
(3.50)\end{array}$ \\
\hline GDP & & $\begin{array}{c}-1.50 * * * \\
(0.06)\end{array}$ & & & & $\begin{array}{c}-6.47 * * * \\
(1.61)\end{array}$ & & \\
\hline INFL & & & $\begin{array}{l}-0.08 \\
(0.05)\end{array}$ & & & & $\begin{array}{c}-2.01 * * \\
(0.85)\end{array}$ & \\
\hline RER & & & & $\begin{array}{c}-0.06 * * * \\
(0.01)\end{array}$ & & & & $\begin{array}{c}-2.71 * * * \\
(0.88)\end{array}$ \\
\hline Constant & $\begin{array}{c}-21.03 * * * \\
(3.34)\end{array}$ & $\begin{array}{c}-23.64 * * * \\
(5.54)\end{array}$ & $\begin{array}{c}-18.24 * * * \\
(3.53)\end{array}$ & $\begin{array}{c}-21.02 * * * \\
(3.90)\end{array}$ & $\begin{array}{c}-116.2 * * * \\
(13.86)\end{array}$ & $\begin{array}{c}-284.9 * * * \\
(43.73)\end{array}$ & $\begin{array}{c}22.10 * * * \\
(5.49)\end{array}$ & $\begin{array}{c}-70.8 \text { **** } \\
(10.31)\end{array}$ \\
\hline
\end{tabular}

Source: Authors, Robust standard errors (in parenthesis) and cluster the standard errors at country level $* * * \mathrm{p}<0.01, * * \mathrm{p}<0.05, * \mathrm{p}<0.1$.

Table 5. Hausman's models specification tests, optimal estimator

\begin{tabular}{lcccccccc}
\hline & \multicolumn{4}{c}{ Return On Assets, ROA } & \multicolumn{3}{c}{ Return On Equity, ROE } \\
\hline MG vs. PMG & Model1 & Model2 & Model3 & Model4 & Model1 & Model2 & Model3 & Model4 \\
Chi2 Statistic & 2,81 & 0,06 & 5,72 & 4,33 & 1,36 & 0,01 & 0,19 & 0,11 \\
P-value & 0,24 & 0,99 & 0,13 & 0,23 & 0,51 & 0,99 & 0,98 & 0,99 \\
\hline DFE vs. PMG & Model1 & Model2 & Model3 & Model4 & Model1 & Model2 & Model3 & Model4 \\
Chi2 Statistic & 0,43 & 0,23 & 1,1 & 1,99 & 0,01 & 0,06 & 0,27 & 0,01 \\
P-value & 0,81 & 0,97 & 0,78 & 0,58 & 0,99 & 0,99 & 0,96 & 0,99 \\
\hline
\end{tabular}

Source: Authors, ***,**, and * indicate that the statistic is statistically significant at the $1 \%, 5 \%$, and $10 \%$ levels, respectively, the calculated Hausman statistic is distributed Chi2.

\section{Conclusion and Policy Implications}

One lesson learned from 2007-2009 financial crises is that banking sector performance and it resilience depends on the macroeconomic environment. Recently, Togolese banking sector indicators deteriorated under favorable macroeconomic conditions: economic growth increased from 2010 to 2015, while banking profitability volatility increased in the same period. This stylized fact pointed out the relationship between the bank sector performance and macroeconomic environment.

Using recent econometric literature as well as economic and financial literature, this article investigate short-run and long-run relationship between three main macroeconomics variables (GDP growth, real effective exchange rate, and inflation) and banking sector profitability (measured by ROA and ROE). 
Results suggest that, in the short-run, banks' return on assets and return on equity are not related to macroeconomics variables. But banks' ROA is determined positively by bank capital to assets ratio and bank size, while banks' ROE is affected negatively by bank capital to assets ratio.

However, in the long-run, real gross domestic product growth and real effective exchange rate affect negatively and statistically significant banks' return on assets, while inflation rate has no effect on banks' return on assets.

Concerning bank's return on equity, long-run results show that real GDP growth, real effective exchange rate, and inflation affect negatively bank's return on equity.

As policy implications, results suggest that to stabilize bank profitability and make banking sector more resilient, policymakers and banking sector managers must, among others, try to improve real GDP growth, real effective exchange rate, and inflation volatility anticipation.

\section{References}

Aburime, T. U. (2009). Determinants of Bank Profitability: Macroeconomic Evidence from Nigeria. International Economics and Finance Journal, 4(1-2), 69-91. https://doi.org/10.2139/ssrn.1231064

Acaravci, S. K., \& Çalim, A. E. (2013). Turkish banking sector's profitability factors. International Journal of Economics and Financial Issues, 3(1), 27.

Addae, A. A., Nyarko-Baasi, M., \& Tetteh, M. L. (2014). Effect of Exchange Rate Movements on Ghanaian Banks. Journal of Finance and Accounting, 2(3), 62-71. https://doi.org/10.11648/j.jfa.20140203.15

Adler, M., \& Dumas, B. (1980). The exposure of long-term foreign currency bonds. Journal of Financial and Quantitative Analysis, 15(04), 973-994. https://doi.org/10.2307/2330573

Asutay, M., \& Izhar, H. (2007). Estimating the profitability of Islamic banking: evidence from bank Muamalat Indonesia. Review of Islamic Economics, 11(2), 17-29.

Bashir, A. H. M. (2003). Determinants of profitability in Islamic banks: Some evidence from the Middle East. Islamic Economic Studies, 11(1), 31-57.

Blackburne, E. F., \& Frank, M. E. (2007). Estimation of Nonstationary Heterogeneous Panels. Stata Journal, 7 , 197-208.

Bolt, W., De Haan, L., Hoeberichts, M., Van Oordt, M. R., \& Swank, J. (2012). Bank profitability during $\begin{array}{lllll}\text { recessions. Journal of Banking \& } & \text { Finance, 36(9), 2552-2564. }\end{array}$ https://doi.org/10.1016/j.jbankfin.2012.05.011

Calza, A., Manrique, M., \&Sousa, J. (2006). Credit in the euro area: An empirical investigation using aggregate data. The Quarterly Review of Economics and Finance, 46(2), 211-226. https://doi.org/10.1016/j.qref.2005.02.001

Chamberlain, S., Howe, J. S., \& Popper, H. (1997). The exchange rate exposure of US and Japanese banking $\begin{array}{lllll}\text { institutions. Journal of Banking \& } & \text { 871-892. }\end{array}$ https://doi.org/10.1016/s0378-4266(97)00002-2

Choi, I. (2001). Unit Root Tests for Panel Data. Journal of International Money and Finance, 20, 249-72. https://doi.org/10.1016/s0261-5606(00)00048-6

Christensen, I., Meh, C., \& Moran, K. (2011). Bank leverage regulation and macroeconomic dynamic. CIRANO-Scientific Publications, 2011s-76. https://doi.org/10.2139/ssrn.1999002

Combey, A. (2016). Private Consumption in the WAEMU Zone: Does Interest Rate Matter? Journal of Economics and Sustainable Development, 7(22), 211-216.

Demirgüç-Kunt, A., \& Huizinga, H. (1999). Determinants of commercial bank interest margins and profitability: Some international evidence. The World Bank Economic Review, 13(2), 379-408. https://doi.org/10.1093/wber/13.2.379

Diamond, D. W., \& Dybvig, P. H. (1983). Bank runs, deposit insurance, and liquidity. The Journal of Political Economy, 401-419. https://doi.org/10.1086/261155

Francis, M. E. (2013). Determinants of commercial bank profitability in Sub-Saharan Africa. International Journal of Economics and Finance, 5(9), 134. https://doi.org/10.5539/ijef.v5n9p134

Gammadigbé, V. (2012). Stress test macroéconomique du système bancaire de l'UEMOA. No. 39214. University Library of Munich, Germany. 
Im, K. S., Pesaran, M. H., \& Shin, Y. (2003). Testing for Unit Roots in Heterogeneous Panels. Journal of Econometrics, 115, 53-74. https://doi.org/10.1016/s0304-4076(03)00092-7

Isaac, L. (2015). Assessing the Impact of Exchange Rate Risk on Banks Performance in Nigeria. Journal of Economics and Sustainable Development, 6(6), 1-13.

Jiménez, G., Ongena, S., Peydró-Alcalde, J. L., \& Saurina, J. (2009). Credit supply: Identifying balance-sheet channels with loan applications and granted loans. CEPR Discussion Paper Series 7655. https://doi.org/10.2139/ssrn.1685370

Khrawish, H. A. (2011). Determinants of commercial banks performance: Evidence from Jordan. International Research Journal of Finance and Economics, 81, 148-159.

Köhler, M. (2015). Which banks are more risky? The impact of loan growth and business model on bank risk-taking. Journal of Financial Stability, 16, 195-212. https://doi.org/10.1016/j.jfs.2014.02.005

Levin, A., Lin, C. F., \& Chu, C. (2002). Unit Root Tests in Panel data: Asymptotic and Finite-sample Properties. Journal of Econometrics, 108, 1-24. https://doi.org/10.1016/s0304-4076(01)00098-7

Luehrman, T. A. (1991). Exchange rate changes and the distribution of industry value. Journal of International Business Studies, 22(4), 619-649. https://doi.org/10.1057/palgrave.jibs.8490317

Maddala, G. S., \& Wu, S. (1999). A Comparative Study of Unit Root Tests with Panel Data and a New Simple Test. Oxford Bulletin of Economics and Statistics, 61, 631-52. https://doi.org/10.1111/1468-0084.61.s1.13

Masood, O., \& Ashraf, M. (2012). Bank-specific and macroeconomic profitability determinants of Islamic banks: The case of different countries. Qualitative Research in Financial Markets, 4(2/3), 255-268. https://doi.org/10.1108/17554171211252565

Osuagwu, E. S. (2014). Determinants of bank profitability in Nigeria. International Journal of Economics and Finance, 6(12). https://doi.org/10.5539/ijef.v6n12p46

Pesaran, M. (2006). Estimation and inference in large heterogeneous panels with a multifactor error structure. Econometrica, 74, 967-1012. https://doi.org/10.1111/j.1468-0262.2006.00692.x

Powo Fosso, B. (2000). Les déterminants des faillites bancaires dans les pays en développement: Le cas des pays de l'Union économique et monétaire Ouest-africaine (UEMOA). Cahier de recherche \#2000-02, Département de sciences économiques, Université de Montréal.

Revell, J. (1979). Inflation \& Financial Institutions. Financial Times Limited.

Saad, W., \& El-Moussawi, C. (2012). The Determinants of Net Interest Margins of Commercial Banks in Lebanon. Journal of Money, Investment and Banking, 23, 118-132.

Scott, A. O., \& Ovuefeyen, E. J. (2014). Effects of Economic Openness and Inflation on Commercial Banks' Profitability: Panel Data Evidence from Nigeria, Post-Banking Sector Consolidation (2005-2012). European Journal of Business and Management, 6(30).

Simiyu, C. N., \& Ngile, L. (2015). Effect of macroeconomic variables on profitability of commercial banks listed in the Nairobi securities exchange. International Journal of Economics, Commerce and Management, 1 .

Sufian, F., \& Habibullah, M. S. (2010). Does economic freedom fosters banks' performance? Panel evidence from Malaysia. Journal of Contemporary Accounting \& Economics, 6(2), 77-91. https://doi.org/10.1016/j.jcae.2010.09.003

Tan, Y., \& Floros, C. (2012). Bank profitability and inflation: The case of China. Journal of Economic Studies, 39(6), 675-696. https://doi.org/10.1108/01443581211274610

Tanimoune, A., \& Cloutier, M. P. (2009). CEA $43^{\text {rd }}$ Annual Conference Thursday, May 28-Sunday, May 31, 2009. University of Toronto, Ontario Microcredit institutions and relative efficiencies in West African Economic and Monetary Union: preliminary results.

Trujillo-Ponce, A. (2013). What determines the profitability of banks? Evidence from Spain. Accounting \& Finance, 53(2), 561-586. https://doi.org/10.1111/j.1467-629x.2011.00466.x

Westerlund, J. (2007). Testing for Error Correction in Panel Data. Oxford Bulletin of Economics and Statistics, 69, 709-748. https://doi.org/10.1111/j.1468-0084.2007.00477.x 


\section{Appendix}

\section{Definitions and Sources of Variables}

\begin{tabular}{|c|c|c|}
\hline Variables & Definitions & Sources \\
\hline Gross domestic product growth & GDP $=$ Gross domestic product $($ constant 2005) growth & \multirow[b]{2}{*}{$\begin{array}{l}\text { World Development Indicators (WDI) } \\
\text { of the World Bank }\end{array}$} \\
\hline Real Effectif Exhange Rate & $\begin{array}{l}\text { RER }=\text { Real effective exchange rate index }(2010=100) \\
\text { (annual percentage) }\end{array}$ & \\
\hline Inflation Rate & INFL $=$ Consumer prices (annual percentage) & $\begin{array}{l}\text { Central Bank of West African States } \\
\text { database }\end{array}$ \\
\hline Return On Assets & ROA $=$ Net Profit $/$ Total Assets (percentage) & \multirow{4}{*}{$\begin{array}{l}\text { Banking Commission of the WAEMU } \\
\text { annual reports }\end{array}$} \\
\hline Return On Equity & ROE $=$ Net Profit / Shareholder's Equity (percentage) & \\
\hline Bank Capital to Assets Ratio & CAR = Bank Capital / Total Assets (percentage) & \\
\hline Bank Size & $\mathrm{BS}=\mathrm{Ln}($ Total Assets) & \\
\hline
\end{tabular}

Source: Authors.

\section{Copyrights}

Copyright for this article is retained by the author(s), with first publication rights granted to the journal.

This is an open-access article distributed under the terms and conditions of the Creative Commons Attribution license (http://creativecommons.org/licenses/by/4.0/). 